\title{
Metallo- $\beta$-lactamase and AmpC genes in Escherichia coli, Klebsiella pneumoniae, and Pseudomonas aeruginosa isolates from abattoir and poultry origin in Nigeria
}

Chika Ejikeugwu', Okoro Nworie ${ }^{2}$, Morteza Saki ${ }^{3 *}$, Hussein O. M. Al-Dahmoshi ${ }^{4}$, Noor S. K. Al-Khafaji ${ }^{4}$, Chika Ezeador ${ }^{5}$, Emmanuel Nwakaeze ${ }^{1}$, Peter Eze ${ }^{6}$, Eniola Oni ${ }^{7}$, Chidiebere Obi ${ }^{8}$, Ifeanyichukwu Iroha ${ }^{1}$, Charles Esimone ${ }^{9}$ and Michael U. Adikwu ${ }^{10}$

\begin{abstract}
Background: Gram-negative bacteria (GNB) including Escherichia coli, Pseudomonas aeruginosa, and Klebsiella pneumoniae represent the most relevant reservoir of resistance genes such as metallo- $\beta$-lactamase (MBL) and AmpC genes that give them the undue advantage to resist antimicrobial onslaught. This study aimed to investigate the occurrence of MBL (b/a $\left.a_{\mathrm{IMP}-1}, b / a_{\mathrm{IMP}-2}, b a_{\mathrm{VIM}-1}, b / a_{\mathrm{VIM}-2}\right)$ and AmpC (b/a $\left.a_{\mathrm{FOX}}, b / a_{\mathrm{DHA}}, b / a_{\mathrm{CMY}}, b / a_{\mathrm{ACC}}\right)$ resistance genes in aforementioned GNB collected from abattoir and poultry sources in Nigeria.

Results: In total, 370 isolates were collected from abattoir tables $(n=130)$, anal region of cows $(n=120)$, and the cloacae of poultry birds $(n=120)$. The test isolates showed high rate of resistance to cephalosporins and carbapenems. The MBLs were phenotypically detected in 22 E. coli, 22 P. aeruginosa, and 18 K. pneumoniae isolates using combined disc test (CDT). However, only 11 E. coli, 24 P. aeruginosa, and 18 Klebsiella pneumoniae isolates were phenotypically confirmed to be AmpC producers using cefoxitin-cloxacillin double disk synergy test (CCDDST). MBL encoding genes (particularly the bla $a_{\mid M P-1}$ genes and bla $a_{I M P-2}$ genes) were detected by polymerase chain reaction (PCR) in $12(54.6 \%)$ E. coli, 15 (83.3\%) K. pneumoniae, and 16 (72.7\%) P. aeruginosa isolates. AmpC genes (particularly the bla $a_{\mathrm{CMY}}$ genes and bla $\mathrm{F}_{\mathrm{FOX}}$ genes) were found in a total of 5 (29.4\%) E. coli isolates, 5 (27.8\%) isolates of K. pneumoniae, and 10 (41.7\%) isolates of P. aeruginosa.

Conclusions: Our study showed the circulation of MBL and AmpC genes in GNB from abattoir and poultry origin in Nigeria. Adoption of regular control policies is necessary to reduce the spread of these species as soon as possible, especially in poultry and slaughterhouses.
\end{abstract}

Keywords: AmpC, Antibiotic resistance, Gram-negative bacteria, Metallo- $\beta$-lactamase, Multidrug resistance, Nigeria

\footnotetext{
* Correspondence: mortezasaki1981@gmail.com

${ }^{3}$ Department of Microbiology, Faculty of Medicine, Ahvaz Jundishapur University of Medical Sciences, Ahvaz, Iran

Full list of author information is available at the end of the article
}

(C) The Author(s). 2021 Open Access This article is licensed under a Creative Commons Attribution 4.0 International License, which permits use, sharing, adaptation, distribution and reproduction in any medium or format, as long as you give appropriate credit to the original author(s) and the source, provide a link to the Creative Commons licence, and indicate if changes were made. The images or other third party material in this article are included in the article's Creative Commons licence, unless indicated otherwise in a credit line to the material. If material is not included in the article's Creative Commons licence and your intended use is not permitted by statutory regulation or exceeds the permitted use, you will need to obtain permission directly from the copyright holder. To view a copy of this licence, visit http://creativecommons.org/licenses/by/4.0/. The Creative Commons Public Domain Dedication waiver (http://creativecommons.org/publicdomain/zero/1.0/) applies to the data made available in this article, unless otherwise stated in a credit line to the data. 


\section{Background}

There is plethora of reports about the prevalence of metallo$\beta$-lactamase (MBL) and AmpC beta-lactamase-producing bacteria in the hospital environment, community, and foodproducing animals [1-3]. The biggest challenge facing the healthcare sectors in developing countries such as Nigeria is the emergence and spread of multidrug-resistant (MDR) bacteria including Escherichia coli, Pseudomonas aeruginosa, and Klebsiella pneumoniae harboring aforesaid elements [4]. Measuring the prevalence of MDR bacteria coupled with rational use of available antibiotics and proper susceptibility testing is critical to reducing the possible risks associated with infections due to multidrug resistance $[5,6]$. Both carbapenem-resistant Enterobacteriaceae and AmpCproducing Gram-negative bacteria (GNB) have emerged as important health issue that is of global health concern $[7,8]$. This trend can adversely affect the World Health Organization (WHO) 'One Health' policy because of the ease with which GNB harboring multidrug resistance genes can zoonotically move from animals to humans and vice versa [9]. The AmpC $\beta$-lactamases are clinically important beta-lactamases that confer antimicrobial resistance to the narrow-spectrum, expanded-spectrum, and broad-spectrum cephalosporins, and $\beta$-lactamase inhibitors such as amoxicillin-clavulanic acid [10, 11]. On the other hand, MBLs are beta-lactamase enzymes which hydrolyze the carbapenems such as imipenem and render them ineffective for therapeutic purposes [2]. The presence of MBLs and AmpC enzymes in the pathogenic bacteria reduces the therapeutic effectiveness of antibiotics because of their multidrug resistance properties. The possible contamination of food and food-producing animals with MDR bacteria harboring MBLs and AmpC enzymes is perhaps a potential source for the wide dissemination of antibiotic resistance [12]. We hypothesized that E. coli, P. aeruginosa, and K. pneumoniae from abattoir origin harbor genetic factors that mediate the production of MBL and AmpC enzymes as important resistance phenotypes. This study aimed to investigate the occurrence rate of $\mathrm{MBL}$ and $\mathrm{AmpC}$ genes in $\mathrm{GNB}$ isolates collected from abattoir and poultry sources in Nigeria.

\section{Results}

Distribution of the bacterial isolates in the abattoir and poultry samples

The distribution of the isolated bacteria is shown in Table 1. A total of 456 non-duplicate isolates were identified as E. coli, $P$. aeruginosa, and $K$. pneumoniae in 370 samples collected. The $E$. coli with frequency of $36.8 \%(168 / 456)$ was the most prevalent species, followed by $P$. aeruginosa $(n=147 ; 32.2 \%)$, and $K$. pneumoniae ( $n=141 ; 30.9 \%)$.

\section{Antimicrobial susceptibility}

The antimicrobial susceptibility testing results are shown in Table 2. The most resistance rate was seen against cefotaxime $(91.7 \%)$ followed by ceftriaxone $(83.6 \%)$, aztreonam (83.1\%), and ciprofloxacin (82.9\%). The carbapenems (imipenem and meropenem) with the susceptibility rate of $46.7 \%$ were the most effective antibiotics. High levels of resistance were noted in the E. coli isolates that showed varying rates of resistance. The $E$. coli isolates showed reduced susceptibility to cephalosporins: ceftriaxone $(n=160 ; 95.2 \%)$, ceftazidime $(n=$ $162 ; 96.4 \%)$ and cefotaxime $(n=165 ; 98.2 \%)$. The resistance pattern most commonly observed amongst the $K$. pneumoniae isolates was resistance to cefotaxime (96.5\%), aztreonam (96.5\%), ceftriaxone (89.4\%), ciprofloxacin $(86.5 \%)$, and ceftazidime (82.3\%). The antibiotic resistance pattern of the organism confirmed that more than $50 \%$ of the $P$. aeruginosa isolates showed high-level of resistance to the carbapenems including imipenem (66.7\%), ertapenem (61.2\%) and meropenem (60.5\%). Reduced susceptibility of the $P$. aeruginosa isolates was also observed in cephalosporins: cefoxitin (80.3\%), cefotaxime (79.6\%), ceftriaxone (64.6\%), and ceftazidime (54.4\%).

\section{Phenotypic characterization of MBL and AmpC enzyme production}

The Table 3 shows the result of the phenotypic confirmation of MBL production in the tested bacteria. MBL producing bacteria was phenotypically detected in a total of $22(13.1 \%)$ E. coli isolates. Among K. pneumoniae isolates, 6, 7, and 5 isolated from abattoir tables, cloacal swabs of poultry birds, and anal swab samples of cows were identified as MBL producers, respectively. In this study, $P$. aeruginosa isolates that produce MBL enzymes were phenotypically detected in abattoir samples (12.5\%), cloacal swab samples (14.6\%), and anal swab samples of cows (18.6\%).

The result of the AmpC enzyme production in the $E$. coli, $K$. pneumoniae, and P. aeruginosa isolates is shown

Table 1 Isolation rate of the Escherichia coli, Pseudomonas aeruginosa, and Klebsiella pneumoniae from different samples

\begin{tabular}{|c|c|c|c|c|}
\hline Organism & $\begin{array}{l}\text { Swabs from abattoir benches }(n= \\
165) \\
n(\%)\end{array}$ & $\begin{array}{l}\text { Cloacal swabs of poultry birds }(n= \\
148) \\
n(\%)\end{array}$ & $\begin{array}{l}\text { Anal swabs of cow }(n= \\
143) \\
n(\%)\end{array}$ & $\begin{array}{l}\text { Total }(n= \\
456) \\
n(\%)\end{array}$ \\
\hline Escherichia coli & $69(41.8)$ & $51(34.5)$ & 48 (33.6) & $168(36.8)$ \\
\hline $\begin{array}{l}\text { Pseudomonas } \\
\text { aeruginosa }\end{array}$ & $56(33.9)$ & $48(32.4)$ & $43(30.1)$ & $147(32.2)$ \\
\hline Klebsiella pneumoniae & $40(24.2)$ & 49 (33.1) & $52(36.4)$ & $141(30.9)$ \\
\hline
\end{tabular}


Table 2 Susceptibility test results of all isolates

\begin{tabular}{|c|c|c|c|c|c|c|c|c|}
\hline \multirow{2}{*}{$\begin{array}{l}\text { Antibiotics } \\
(\mu \mathrm{g})\end{array}$} & \multicolumn{2}{|c|}{ Escherichia coli } & \multicolumn{2}{|c|}{ Klebsiella pneumoniae } & \multicolumn{2}{|c|}{ Pseudomonas aeruginosa } & \multicolumn{2}{|l|}{ Total } \\
\hline & $\begin{array}{l}\text { S } \\
\text { n (\%) }\end{array}$ & $\begin{array}{l}\text { R } \\
\text { n (\%) }\end{array}$ & $\begin{array}{l}\text { S } \\
\text { n (\%) }\end{array}$ & $\begin{array}{l}\text { R } \\
\text { n (\%) }\end{array}$ & $\begin{array}{l}\text { S } \\
\text { n (\%) }\end{array}$ & $\begin{array}{l}\text { R } \\
\text { n (\%) }\end{array}$ & $\begin{array}{l}\text { S } \\
\text { n (\%) }\end{array}$ & $\begin{array}{l}\text { R } \\
\text { n (\%) }\end{array}$ \\
\hline CRO (30) & $8(4.8)$ & $160(95.2)$ & $15(10.6)$ & $126(89.4)$ & $52(35.4)$ & $95(64.6)$ & $75(16.4)$ & $381(83.6)$ \\
\hline FOX (30) & $43(25.6)$ & $125(74.4)$ & $35(24.8)$ & $106(75.2)$ & $29(19.7)$ & $118(80.3)$ & $107(23.5)$ & $349(76.5)$ \\
\hline IPM (10) & $81(48.2)$ & $87(51.8)$ & $83(58.9)$ & $58(41.1)$ & 49 (33.3) & $98(66.7)$ & $213(46.7)$ & $243(53.3)$ \\
\hline CAZ (30) & $6(3.6)$ & $162(96.4)$ & $25(17.7)$ & $116(82.3)$ & $67(45.6)$ & $80(54.4)$ & $98(21.5)$ & $358(78.5)$ \\
\hline ETP (10) & $22(13.1)$ & $146(86.9)$ & $22(15.6)$ & $119(84.4)$ & $57(38.8)$ & $90(61.2)$ & $101(22.1)$ & $355(77.9)$ \\
\hline OFX (5) & $49(29.2)$ & $119(70.8)$ & $49(34.8)$ & $92(65.2)$ & $54(36.7)$ & $93(63.3)$ & $152(33.3)$ & $304(66.7)$ \\
\hline GM (10) & $73(43.5)$ & $95(56.5)$ & $55(39.0)$ & $86(61.0)$ & $65(44.2)$ & $82(55.8)$ & $193(42.3)$ & $263(57.7)$ \\
\hline AK (10) & $59(35.1)$ & $109(64.9)$ & $67(47.5)$ & $74(52.5)$ & $53(36.1)$ & $94(63.9)$ & $179(39.3)$ & $277(60.7)$ \\
\hline CIP (5) & $31(18.5)$ & $137(81.5)$ & $19(13.5)$ & $122(86.5)$ & 28 (19.0) & $119(81.0)$ & 78 (17.1) & $378(82.9)$ \\
\hline CTX (30) & $3(1.8)$ & 165 (98.2) & $5(3.5)$ & $136(96.5)$ & 30 (20.4) & 117 (79.6) & $38(8.3)$ & 418 (91.7) \\
\hline MEM (10) & 75 (44.6) & $93(55.4)$ & $80(56.7)$ & $61(43.3)$ & $58(39.5)$ & $89(60.5)$ & $213(46.7)$ & $243(53.3)$ \\
\hline AMP (10) & $50(29.8)$ & $118(70.2)$ & $43(30.5)$ & $98(69.5)$ & $28(19.0)$ & $119(81.0)$ & $121(26.5)$ & 335 (73.5) \\
\hline ATM (30) & $11(6.5)$ & $157(93.5)$ & $5(3.5)$ & $136(96.5)$ & $61(41.5)$ & $86(58.5)$ & 77 (16.9) & 379 (83.1) \\
\hline
\end{tabular}

S Susceptible, R Resistant, IPM Imipenem, MEM Meropenem, ETP Ertapenem, FOX Cefoxitin, CAZ Ceftazidime, AK Amikacin, GM Gentamicin, CTX Cefotaxime, CRO Ceftriaxone, CIP Ciprofloxacin, OFX Ofloxacin, AMP Ampicillin, ATM Aztreonam

in Table 4. AmpC enzyme was phenotypically detected in $E$. coli isolates from abattoir (8.7\%), cloacal swab samples $(9.8 \%)$, and anal swabs of cows (12.5\%). On the other hand, 9 isolates of $P$. aeruginosa (16.1\%) from abattoir tables and 7 isolates (14.6\%) from poultry sources were confirmed as AmpC enzyme producers. It was also found that 8 isolates of $P$. aeruginosa (18.6\%) from the anal swabs of cows were phenotypically confirmed as AmpC enzyme producers. AmpC enzyme production amongst the $K$. pneumoniae isolates was $15.0 \%$ in abattoir tables, $12.2 \%$ in poultry specimens and $11.5 \%$ in the anal swabs of cows. The MBL and AmpC positive Klebsiella species have MARI of 0.4 to 0.5 , while the MBL and AmpC positive E. coli isolates have MARI of 0.4 to 0.6 . The $P$. aeruginosa isolates that were positive for MBL and AmpC enzyme production had a MARI of 0.7

Table 3 Phenotypic occurrence of metallo- $\beta$-lactamase (MBL) in studied bacteria

\begin{tabular}{lll}
\hline Bacteria (n) & Source & Positive MBL n (\%) \\
\hline Escherichia coli (69) & Abattoir & $8(11.6)$ \\
Escherichia coli (51) & Poultry & $7(13.7)$ \\
Escherichia coli (48) & Anal swabs of cow & $7(14.6)$ \\
Pseudomonas aeruginosa (56) & Abattoir & $7(12.5)$ \\
Pseudomonas aeruginosa (48) & Poultry & $7(14.6)$ \\
Pseudomonas aeruginosa (43) & Anal swabs of cow & $8(18.6)$ \\
Klebsiella pneumoniae (40) & Abattoir & $6(15.0)$ \\
Klebsiella pneumoniae (49) & Poultry & $7(14.3)$ \\
Klebsiella pneumoniae (52) & Anal swabs of cow & $5(9.6)$ \\
Total (456) & & $62(13.6)$ \\
\hline
\end{tabular}

to 0.8. The MARI result showed that the MBL and AmpC positive $K$. pneumoniae and $E$. coli isolates were multiply resistant to more than four antibiotic classes while the $P$. aeruginosa isolates that were positive for MBL and AmpC enzyme production were multiply resistant to more than seven antibiotics.

\section{PCR detection of MBL and AmpC genes}

The result of gene amplification of MBL and AmpC gene in the tested isolates is shown in Tables 5 and 6 . Only the $b l a_{\mathrm{IMP}}$ MBL gene family was detected by PCR in this study. The $b l a_{\mathrm{VIM}-1}$ and $b l a_{\mathrm{VIM}-2} \mathrm{MBL}$ genes were not detected in the MBL phenotypes. Overall, the prevalence of bla $_{\mathrm{IMP}-1}$ gene in the MBL phenotypes was $36.4 \%$ (8/22), $50 \%(9 / 18)$, and $54.5 \%(12 / 22)$ for E. coli, K. pneumoniae, and $P$. aeruginosa, respectively. The bla $_{\mathrm{IMP}-2}$ gene was detected at the rate of $18.2 \%(4 / 22)$, $33.3 \%(6 / 18)$, and $18.2 \%$ (4/22) for E. coli, K. pneumoniae, and $P$. aeruginosa isolates, respectively. Also, only the $b l a_{\mathrm{CMY}}$ and $b l a_{\mathrm{FOX}}$ genes were detected in the studied isolates used in this study. Out of the 17 isolates of E. coli, only $3(17.6 \%)$ and $2(11.8 \%)$ isolates harbored the $b l a_{\mathrm{CMY}}$ and $b l a_{\mathrm{FOX}}$ genes, respectively. Four out of the $18(22.2 \%) K$. pneumoniae isolates harbored the $b l a_{\mathrm{CMY}}$ gene, while only one isolate $(5.6 \%)$ harbored the bla $a_{\mathrm{FOX}}$ gene. The $b l a_{\mathrm{CMY}}$ and $b l a_{\mathrm{FOX}}$ genes were detected by PCR in $7(29.2 \%)$ and $3(12.5 \%)$ P. aeruginosa isolates, respectively. The co-existence of genes was not detected in any isolates. There was no association among the frequency of $\mathrm{MBL}$ and $\mathrm{AmpC}$ resistance genes with the studied isolates $(P$-value $>0.05)$ (Table 7). 
Table 4 Phenotypic occurrence of AmpC producing bacteria

\begin{tabular}{lll}
\hline Organism (n) & Source & AmpC positive $\mathbf{n}(\%)$ \\
\hline Escherichia coli (69) & Abattoir & $6(8.7)$ \\
Escherichia coli (51) & Poultry & $5(9.8)$ \\
Escherichia coli (48) & Anal swabs of cow & $6(12.5)$ \\
Pseudomonas aeruginosa (56) & Abattoir & $9(16.1)$ \\
Pseudomonas aeruginosa (48) & Poultry & $7(14.6)$ \\
Pseudomonas aeruginosa (43) & Anal swabs of cow & $8(18.6)$ \\
Klebsiella pneumoniae (40) & Abattoir & $6(15.0)$ \\
Klebsiella pneumoniae (49) & Poultry & $6(12.2)$ \\
Klebsiella pneumoniae (52) & Anal swab of cow & $6(11.5)$ \\
Total (456) & & $59(12.9)$
\end{tabular}

\section{Discussion}

In this study, environmental samples from poultry, abattoir, and anal swabs of cows were bacteriologically analyzed for the isolation of E. coli, K. pneumoniae, and $P$. aeruginosa for multidrug resistance genes that encode MBL and AmpC enzymes production. The occurrence rates of 32.2 and $30.9 \%$ for $P$. aeruginosa and $K$. pneumonia in this study were higher than report by Savin et al. [13] from Germany who exhibited frequency rates of 5.1 and $10.8 \%$ for $P$. aeruginosa and K. pneumoniae, respectively. However, the occurrence rate of $36.8 \%$ for E. coli isolates was lower (39.4\%) than that of Savin et al. Meanwhile, various previous studies in line with the current results, have shown a higher prevalence of $E$. coli in samples collected from environmental origin including poultry wastewater, and slaughter houses [13, 14]. The prevalence of GNB in slaughter houses and poultry farms is obvious due to the colonization of the gastrointestinal tract of animals with a variety of bacteria. However, since this high volume of bacteria may enter the human food chain and eventually lead to bacterial infections and the spread of antibiotic resistance, strict control policies should be implemented in the developing countries such as Nigeria to reduce the spread of

Table 5 Total occurrence of MBL and AmpC genes in all 456 isolates

\begin{tabular}{ll}
\hline Genes & $\begin{array}{l}\text { Occurrence } \\
\mathbf{n}(\%)\end{array}$ \\
\hline bla $_{\mathrm{IMP}-1}$ & $29(6.4)$ \\
bla $a_{\mathrm{IMP}-2}$ & $14(3.1)$ \\
bla $a_{\mathrm{VIM}-1}$ & $0(0.0)$ \\
bla $a_{\mathrm{VIM}-2}$ & $0(0.0)$ \\
bla $a_{\mathrm{CMY}}$ & $14(3.1)$ \\
bla $a_{\mathrm{FOX}}$ & $6(1.3)$ \\
bla $a_{\mathrm{DHA}}$ & $0(0.0)$ \\
blacC & $0(0.0)$ \\
\hline
\end{tabular}

MDR bacteria and increase the hygiene level of aforesaid environments $[15,16]$.

Abattoirs and poultry farms are good grounds for the evolution and spread of antibiotic resistant bacteria [17, 18]. The result of the AST in this study revealed a high level of resistance of E. coli, K. pneumoniae, and P. aeruginosa to more than $50 \%$ of the tested antibiotic panels including the cephalosporins, aminoglycosides, quinolones, and carbapenems. This is a possible indication of the stealth and exceptional emergence and spread of resistant GNB in the non-hospital environment. The results of this study were in parallel with the previous studies from Australia, China, and Switzerland that were suggestive of the ability of resistant GNB to cause a public health problem through the food chain, especially in climes where antibiotics are used irrationally in nonclinical practices [17-20]. In this study, the high resistance rates $(>70 \%)$ against third-generation cephalosporins (TGCs) were similar to previous report by Otokunefor et al. [21] from Nigeria who reported a resistance rate of $\geq 80 \%$ against TGCs family. Also, in accordance with the findings of this study, a high resistance rate against quinolones/fluoroquinolones was reported previously by a research from Romania [22]. However, the excessive high levels of resistance to quinolones (more than 60\%) in comparison to a study from Iran by Talebiyan et al. [23] who reported a low resistance rate of $7.5 \%$ against ciprofloxacin is a cause for concern and makes the adoption of control measures clearer in Nigeria. The resistance rates against aminoglycosides family including amikacin and gentamicin were 60.7 and $57.7 \%$, respectively, which were close to preceding report (58.4\%) from Thailand and Cambodia [14]. In this study, $83.1 \%$ of isolates were resistant against aztreonam that was comparable to previous report by Elhariri et al. [24] who reported a $76.1 \%$ of resistance rate in $P$. aeruginosa isolates collected from camel meat samples at two major abattoirs in Egypt. Another finding of current study was the higher resistance rate of $73.5 \%$ 
Table 6 Occurrence of MBL and AmpC genes variants among phenotypic MBL and AmpC positive Escherichia coli, Klebsiella pneumoniae, and Pseudomonas aeruginosa

\begin{tabular}{|c|c|c|c|c|}
\hline Genes & $\begin{array}{l}\text { Escherichia coli }(n=22) \\
\text { n (\%) }\end{array}$ & $\begin{array}{l}\text { Klebsiella pneumoniae }(n=18) \\
\text { n (\%) }\end{array}$ & $\begin{array}{l}\text { Pseudomonas aeruginosa }(n=22) \\
\text { n (\%) }\end{array}$ & $\begin{array}{l}\text { Total }(n=62) \\
\text { n (\%) }\end{array}$ \\
\hline \multicolumn{5}{|c|}{ MBL gene } \\
\hline$b / a_{\mid \mathrm{MP}-1}$ & $8(36.4)$ & $9(50)$ & $12(54.5)$ & 29 (46.8) \\
\hline$b / a_{\mid \mathrm{MP}-2}$ & $4(18.2)$ & $6(33.3)$ & $4(18.2)$ & $14(22.6)$ \\
\hline \multirow[t]{2}{*}{ Total } & $12(54.6)$ & $15(83.3)$ & $16(72.7)$ & $43(69.4)$ \\
\hline & $\begin{array}{l}\text { Escherichia coli }(n=17) \\
\mathrm{n}(\%)\end{array}$ & $\begin{array}{l}\text { Klebsiella pneumoniae }(n=18) \\
\text { n (\%) }\end{array}$ & $\begin{array}{l}\text { Pseudomonas aeruginosa }(n=24) \\
\text { n (\%) }\end{array}$ & $\begin{array}{l}\text { Total }(n=59) \\
\text { n (\%) }\end{array}$ \\
\hline \multicolumn{5}{|c|}{ AmpC gene } \\
\hline$b l a_{\mathrm{CMY}}$ & $3(17.6)$ & $4(22.2)$ & $7(29.2)$ & $14(23.7)$ \\
\hline bla & $2(11.8)$ & $1(5.6)$ & $3(12.5)$ & $6(10.2)$ \\
\hline Total & $5(29.4)$ & $5(27.8)$ & $10(41.7)$ & 20 (33.9) \\
\hline
\end{tabular}

against ampicillin in comparison to the research by Dsani et al. [25] from Ghana who reported resistance rate of $57 \%$ in $E$. coli isolates from raw meat.

One of the noteworthy results of this study was the high resistance of isolates to carbapenems. Although in this research the resistance of more than $50 \%$ of isolates against carbapenems was very worrying, but still this category showed the highest efficacy among the studied antibiotics. In this study, the ertapenem with the susceptibility rate of $22.1 \%$ was the less effective carbapenem, while meropenem and imipenem were more effective. In the previous study from Palestinian territory, in contrary to this study, low resistance rates of 3 and $34 \%$ were reported against meropenem and imipenem, respectively [26]. One of the reasons for the presence of carbapenem-resistant bacteria in slaughter or poultry environments may be due to the use of broad-spectrum cephalosporins in these areas [3]. The exact link between the use of broad-spectrum cephalosporins and carbapenem resistance has not been fully investigated and disclosed. However, plasmids carrying both genes for resistance against TGCs $\left(b l a_{\mathrm{ACC}-1}\right)$ and carbapenems $\left(\right.$ bla $\left.a_{\mathrm{VIM}-1}\right)$ have been found in bacteria isolated from farm animals [27].
In this study, we carried out CDT and CC-DDST to evaluate the presence of $\mathrm{MBL}$ and $\mathrm{AmpC}$ enzymes in the test GNB of E. coli, K. pneumoniae, and P. aeruginosa isolates. We also carried out PCR to determine the genes underpinning the multidrug resistance profile of the GNB. This current study was a follow-up to elucidate and give impetus to our previous studies on the emergence and spread of multidrug-resistant GNB in the community and the need to be on the lookout for these pathogens to forestall any disease outbreak due to them. Generally, most of the comprehensive data on MBL and AmpC producing GNB are from America, Europe, and partly Asia. There is still paucity of data on the prevalence of these pathogens in Africa and Nigeria. Today, there are various phenotypic methods for detection of different beta-lactamases, none of which have the sensitivity and specificity of molecular methods such as PCR and sequencing [28]. In this study, the total rates of phenotypic prevalence of studied MBLs and AmpC were $13.6 \%(62 / 456)$ and $12.9 \%$ (59/456), respectively. In the previous report by Ibadin et al. [29], lower rates of MBLs (8.1\%) and AmpC (7.8\%) were disclosed in GNB collected from clinical samples in Benin City, Nigeria. In another research from Italy the occurrence rate of $20 \%$

Table 7 The MBL and AmpC gene presence association among the E. coli, Klebsiella pneumoniae, and Pseudomonas aeruginosa

\begin{tabular}{|c|c|c|c|c|}
\hline Gene & $\begin{array}{l}\text { Escherichia coli }(n=168) \\
\mathrm{n}(\%)\end{array}$ & $\begin{array}{l}\text { Klebsiella pneumoniae }(n=141) \\
\mathrm{n}(\%)\end{array}$ & $\begin{array}{l}\text { Pseudomonas aeruginosa }(n=147) \\
\text { n (\%) }\end{array}$ & $P$-value \\
\hline bla $a_{\mathrm{MP}-1}$ & $8(5.0)$ & $9(6.0)$ & $12(8.2)$ & 0.466901 \\
\hline$b l a_{1 \mathrm{MP}-2}$ & $4(2.0)$ & $6(4.0)$ & $4(2.7)$ & 0.608398 \\
\hline bla $a_{\mathrm{VIM}-1}$ & 0 & 0 & 0 & - \\
\hline bla $a_{\mathrm{VIM}-2}$ & 0 & 0 & 0 & - \\
\hline$b / a_{\mathrm{CMY}}$ & $3(1.8)$ & $4(2.8)$ & $7(4.8)$ & 0.305612 \\
\hline$b / a_{\mathrm{DHA}}$ & 0 & 0 & 0 & - \\
\hline$b l a_{\mathrm{ACC}}$ & 0 & 0 & 0 & - \\
\hline$b / a_{\mathrm{FOX}}$ & $2(1.2)$ & $1(0.7)$ & $3(2.0)$ & 0.602015 \\
\hline
\end{tabular}


for MBLs and 16.7\% for AmpC were stated in GNB collected from samples of fresh vegetables and ready-to-eat prepacked salads [30]. The difference in the prevalence rate of $\beta$-lactamases in these studies may be due to dissimilarities in the source of the sample collection and the methods used in the phenotypic detection of enzymes. Also, the results of phenotypic methods in the current experiment showed a higher prevalence of $\beta$ lactamase enzymes compared to PCR. The reason for this phenomenon can be due to the insensitivity and non-specificity of phenotypic methods and the existence of other genes such as bla $a_{\mathrm{NDM}}$ that were not considered in this study due to severe financial constraints. Although the presence of genes such as $b l a_{\mathrm{NDM}}$ and other MBLs has been rarely reported in animals, the investigation of these genes in the future studies will reveal more epidemiologic knowledge in our region [31].

The production of MBL and AmpC by GNB is worrisome because these pathogens have the exceptional ability to resist the antimicrobial onslaughts of carbapenems which are last-line antibiotics used in clinical medicine. The PCR method revealed the most incidences of MBL and AmpC genes in P. aeruginosa isolates followed by $K$. pneumoniae and E. coli. This survey revealed the total occurrence rates of $6.4 \%$ (29/456), 3.1\% (14/456), 3.1\% (14/456), and $1.3 \%(6 / 456)$ for $b l a_{\mathrm{IMP}-1,}, b l a_{\mathrm{IMP}-2,}, b l a_{\mathrm{CMY}}$, and $b l a_{\mathrm{FOX}}$, respectively. Unlike to the current results, a high frequency of bla $a_{\mathrm{CMY}}(26.4 \%)$ was reported in companion animals in a study by Hong et al. [32] from South Korea, while $b l a_{\mathrm{IMP}}, b l a_{\mathrm{VIM}}$, and $b l a_{\mathrm{FOX}}$ genes were not detected. In several earlier studies, the most reported AmpC gene was the $b l a_{\mathrm{CMY}}$ gene [33]. As well, in this study, the $b l a_{\mathrm{VIM}}, b l a_{\mathrm{DHA}}$, and $b l a_{\mathrm{ACC}}$ were not detected, while Hong et al. [32] reported the occurrence of bla $a_{\mathrm{VIM}}$ and $b l a_{\mathrm{DHA}}$ in their study. This showed that, epidemiologically, there are vast variances in different regions. These differences may be due to the dissimilarity in sample size, the method used for detection of various $\beta$ lactamase, and the source of sample collection.

\section{Limitation}

In this study we do not sequence the PCR products due to the low financial sources. Another limitation was the lack of a modern technique such as multilocus sequence typing (MLST) and pulsed-field gel electrophoresis (PFGE) to determine the clonality of isolates.

\section{Conclusions}

Antimicrobial resistance is fast becoming a significant global public health crisis that warrants concerted and sustainable measures to contain. And top amongst this is the effective surveillance, monitoring, detection, and prompt reporting of the development and spread of antimicrobial resistance in zoonotic and nosocomial pathogens, a practice which is still far-fetched in developing countries like Nigeria. The MBLs and AmpC genes detected amongst the isolates give GNB the undue advantage to resist the antimicrobial onslaught of antibiotics. The findings from this research are of major concern as scientific evidence from around the world continues to suggest that the overuse and inappropriate use of antibiotics in animal husbandry and poultry production contribute significantly to the emergence and spread of antibiotic resistant bacteria in the community. The epidemiological data from our work can serve as the basis for the development and establishment of antibiotic resistance surveillance unit's across Nigeria's states to assuage any disease outbreak due to these resistant strains.

\section{Methods}

Ethics

All methods in this study were carried out in accordance with the U.K. Animals (Scientific Procedures) Act, 1986 and associated guidelines, EU Directive 2010/63/EU for animal experiments. All experimental protocols of this study were approved by the Ethics Committee of Ebonyi State University, Nigeria, and all methods were carried out in compliance with the ARRIVE guidelines.

\section{Sample collection}

Sample size determination for this study was determined by the Cochran's formula. A total of 370 non-duplicate abattoir and poultry samples collected from abattoir benches $(n=130)$, anal region of cows $(n=120)$, and the cloacae of poultry birds, particularly broilers $(n=120)$ were recruited for this research from January to August 2019.

\section{Isolation of bacteria}

The isolation, characterization, and identification of $E$. coli, K. pneumoniae, and P. aeruginosa from the abattoir and poultry samples was carried out using standard microbiology techniques including culture techniques, microscopy, biochemical testing, morphological and colonies features of the bacteria on selective culture media [34]. The isolates were bacteriologically, biochemically and microscopically confirmed to be E. coli, Klebsiella pneumoniae, and P. aeruginosa. E. coli ATCC 25922, P. aeruginosa ATCC 10145, and $K$. pneumoniae ATCC 700603 was used as control strains.

\section{Antimicrobial susceptibility testing (AST)}

The modified Kirby-Bauer disk diffusion method was used for AST as per the guideline of Clinical Laboratory Standard Institute (CLSI) using single antibiotic discs: imipenem (IPM), meropenem (MEM), ertapenem (ETP), cefoxitin (FOX), ceftazidime (CAZ), amikacin (AK), 
gentamicin (GM), cefotaxime (CTX), ceftriaxone (CRO), ciprofloxacin (CIP), ofloxacin (OFX), ampicillin (AMP), aztreonam (ATM) on Mueller-Hinton (MH) agar plate (Oxoid, UK) according to a previous methodology [15, 35]. All test isolates were adjusted to 0.5 McFarland turbidity standard prior to culture and sensitivity study, and incubated at $37^{\circ} \mathrm{C}$ for $18-24 \mathrm{~h}$. The zone of inhibition was measured, recorded, and interpreted as susceptible $(\mathrm{S})$, and resistant (R) using standard antibiotic breakpoints as stated by the CLSI [35].

\section{Multiple antibiotic resistance index (MARI)}

The MARI indexes were determined for those bacterial isolates that showed positivity to $\mathrm{MBL}$ and $\mathrm{AmpC}$ enzymes production using a previously described methodology according to the following formula:

MARI $=\frac{\text { Total number of antibiotics that each isolate was resistant against them }}{\text { Total number of tested antibiotics for each islates }}$

[36].

\section{Phenotypic screening and detection of MBL and AmpC enzymes}

E. coli, Klebsiella pneumoniae, and P. aeruginosa isolates that were found to show reduced susceptibility to the tested cephalosporins and carbapenems as per the antibiotic breakpoints recommended by CLSI for screening isolates for $\mathrm{MBL}$ and $\mathrm{AmpC}$ enzymes were phenotypically confirmed by previous methods for MBL and AmpC enzyme production using imipenem/ imipenem + EDTA combined disc test (CDT) and the cefoxitin-cloxacillin double-disk synergy test (CCDDST), respectively $[37,38]$.
Isolation and preparation of DNA

DNA isolation and purification were carried out using the Zymo DNA miniprep kit (Epigenetics Company, USA) according to the manufacturer's instruction. The extracted DNA samples were later stored at $-20^{\circ} \mathrm{C}$ for the polymerase chain reaction (PCR) experiment.

\section{PCR detection of MBL and AmpC genes}

The PCR amplification was performed in a thermal cycler (Lumex instrument, Canada) using specific primers (Table 8) synthesized and supplied by Inqaba Biotechnical Industries Ltd. (South Africa) as previously described $[39,40]$. A final PCR mixture of $25 \mu \mathrm{l}$ containing $0.2 \mu \mathrm{l}$ of Taq polymerase enzyme $(5 \mathrm{U} / \mu \mathrm{L}), 2.5 \mu \mathrm{l}$ of $10 \mathrm{X}$ PCR buffer along with $2.5 \mu \mathrm{l} \mathrm{MgCl} 2(25 \mathrm{mM}), 1 \mu \mathrm{l}$ of $10 \mathrm{pM}$ from each of the forward and reverse primers, $2.5 \mu \mathrm{l}$ of dNTPs MIX $(2 \mathrm{mM}), 3 \mu \mathrm{l}$ of DNA template (from the test isolates), and $12.3 \mu \mathrm{l}$ of nuclease-free water were used for PCR amplification of MBL and AmpC genes. PCR amplification conditionfor the MBL genes was as follows: initial denaturation temperature at $95^{\circ} \mathrm{C}$ for 2 min, followed by 25 cycles of DNA denaturation at $95^{\circ} \mathrm{C}$ for $30 \mathrm{~s}$, annealing (according to reference [19]) for $30 \mathrm{~s}$, primer extension at $72{ }^{\circ} \mathrm{C}$ for $30 \mathrm{~s}$, and a final extension step at $72^{\circ} \mathrm{C}$ for $5 \mathrm{~min}$. An MBL gene carrying $\mathrm{K}$. pneumoniae from our previous study was used as a positive control [16]. The PCR amplification of AmpC genes was performed in following condition: initial denaturation temperature at $94{ }^{\circ} \mathrm{C}$ for $3 \mathrm{~min}$, followed by 25 cycles of DNA denaturation at $94{ }^{\circ} \mathrm{C}$ for $30 \mathrm{~s}$, annealing at $64{ }^{\circ} \mathrm{C}$ for $30 \mathrm{~s}$, primer extension at $72^{\circ} \mathrm{C}$ for $1 \mathrm{~min}$, and a final extension at $72^{\circ} \mathrm{C}$ for $7 \mathrm{~min}$. An AmpC gene carrying $P$. aeruginosa from a previous study was used as a positive control [15].

Table 8 Primer sequences for amplification of MBL and AmpC genes

\begin{tabular}{|c|c|c|c|}
\hline Gene targets & Primer sequence (5' to $3^{\prime}$, as synthesized) & Expected amplicon size (bp) & Reference \\
\hline \multicolumn{4}{|l|}{ MBL genes } \\
\hline$b / a_{\mid \mathrm{MP}-1}$ & F1 (5'-ACCGCAGCAGAGTCTTTGCC-3') R1 (5'-ACAACCAGTITTGCCTTACC-3') & 587 & [39] \\
\hline$b / a_{\mid \mathrm{MP}-2}$ & F2 (5'-GTTTATGTGTATGCTTCC-3') R2 (5'-AGCCTGTTCCCATGTAC-3') & 678 & [39] \\
\hline bla $a_{\mathrm{VIM}-1}$ & F3 (5'-AGTGGTGAGTATCCGACAG-3') R3 (5'-ATGAAAGTGCGTGGAGAC-3') & 261 & [39] \\
\hline bla $a_{\mathrm{VIM}-2}$ & F4 (5'-ATGTTCAAACTTITGAGTAAG-3') R4 (5'-CTACTCAACGACTGAGCG-3') & 801 & [39] \\
\hline \multicolumn{4}{|l|}{ AmpC genes } \\
\hline \multirow[t]{2}{*}{$b a_{\mathrm{CMY}}$} & F1 (5'-GCTGCTCAAGGAGCACAGGAT-3') & 520 & [40] \\
\hline & R1 (5'-CACATTGACATAGGTGTGGTG-3') & & \\
\hline \multirow[t]{2}{*}{$b l a_{\mathrm{DHA}}$} & F1 (5'-AACTTTCACAGGTGTGCTGGGT-3') & 405 & [40] \\
\hline & R1 (5'-CCGTACGCATACTGGCTTTGC-3') & & \\
\hline \multirow[t]{2}{*}{$b l a_{\mathrm{ACC}}$} & F1 (5'-AACAGCCTCAGCAGCCGGTTA-3') & 346 & {$[40]$} \\
\hline & R1 (5'-TTCGCC GCAATCATCCCTAGC-3') & & \\
\hline \multirow[t]{2}{*}{$b l a_{\mathrm{FOX}}$} & F1 (5'-AACATG GGGTATCAGGGAGATG-3') & 190 & {$[40]$} \\
\hline & R1 (5'-CAAAGCGCGTAACCGGATTGG-3') & & \\
\hline
\end{tabular}




\section{Gel electrophoresis}

Agarose gel electrophoresis of the PCR products was carried out using 1.5\% agarose gel with ethidium bromide for $1 \mathrm{~h}$ at $80 \mathrm{~V}$. The visual output of the amplicons was captured using an electrophoresis photography system (FotodyneFoto/Analyst Investigator, Fotodyne, Japan).

\section{Statistical analysis}

Statistical evaluation was performed using SPSS, version 21.0 (Armonk, NY, USA). The analyzed data were presented as the descriptive frequencies. The comparison of variables was done by Fisher's exact test and the $p$-value less than 0.05 was considered as a statistically significant association.

\section{Abbreviations}

CC-DDST: Cefoxitin-cloxacillin double disk synergy test; CDT: Combined disc test; CLSI: Clinical Laboratory Standard Institute; GNB: Gram-negative bacteria; MBL: Metallo- $\beta$-lactamase; MDR: Multidrug-resistant; PCR: Polymerase chain reaction; WHO: World Health Organization

\section{Acknowledgements}

The authors acknowledge support received from the members of staff of Biotechnology Research and Development Center (BRDC) of Ebonyi State University, Abakaliki, Nigeria, for helping out in the molecular aspect of this work.

\section{Authors' contributions}

CEj, ON, CE, CEs designed the studies. CEj, EN, PE, EO, CO, II, MUA performed bacterial identification, antibacterial susceptibility testing, and PCR. MS, HOMAD, NSKAK wrote the manuscript with contributions from all authors. CEj, CEs, and MS revised the manuscript. All authors contributed to data analysis, drafting and critically revising the paper and agree to be accountable for all aspects of the work. All authors read and approved the final manuscript.

\section{Funding}

None.

\section{Availability of data and materials}

All data generated or analyzed during this study are included here and are availablefrom the corresponding author on reasonable request.

\section{Declarations}

\section{Ethics approval and consent to participate}

All methods in this study were carried out in accordance with the U.K. Animals (Scientific Procedures) Act, 1986 and associated guidelines, EU Directive 2010/63/EU for animal experiments. All experimental protocols of this study were approved by the Ethics Committee of Ebonyi State University, Nigeria, and all methods were carried out in compliance with the ARRIVE guidelines.

\section{Consent for publication}

Not applicable.

\section{Competing interests}

The authors declare that they have no competing interests.

\section{Author details}

1 Department of Applied Microbiology, Ebonyi State University, Abakaliki, Nigeria. ${ }^{2}$ Department of Biological Sciences, Alex Ekwueme Federal University, Ndufu-Alike Ikwo, Ikwo, Nigeria. ${ }^{3}$ Department of Microbiology, Faculty of Medicine, Ahvaz Jundishapur University of Medical Sciences, Ahvaz, Iran. ${ }^{4}$ Biology Department, College of Science, University of Babylon, Hilla City, Babylon Province, Iraq. ${ }^{5}$ Department of Medical Microbiology \&
Parasitology, Nnamdi Azikiwe University, Awka, Nigeria. ${ }^{6}$ Department of Environmental Health Science, Nnamdi Azikiwe University, Awka, Nigeria. ${ }^{7}$ Department of Microbiology, Federal University of Agriculture, Abeokuta, Nigeria. ${ }^{8}$ Department of Microbiology, Federal University, Birnin Kebbi, Nigeria. ${ }^{9}$ Department of Pharmaceutical Microbiology and Biotechnology, Nnamdi Azikiwe University, Awka, Nigeria. ${ }^{10}$ Department of Pharmaceutics, University of Nigeria, Nsukka, Nigeria.

Received: 26 November 2020 Accepted: 30 March 2021

Published online: 21 April 2021

\section{References}

1. Cesa-Luna C, Baez A, Quintero-Hernández V, Cruz-Enriquez JD, CastañedaAntonio MD, Muñoz-Rojas J. The importance of antimicrobial compounds produced by beneficial bacteria on the biocontrol of phytopathogens. Acta Biol Colomb. 2020;25(1):140-54. https://doi.org/10.15446/abc.v25n1.76867.

2. Hammoudi Halat D, Ayoub Moubareck C. The current burden of carbapenemases: review of significant properties and dissemination among gram-negative bacteria. Antibiotics. 2020;9(4):186. https://doi.org/10.3390/a ntibiotics9040186.

3. Bonardi S, Pitino R. Carbapenemase-producing bacteria in food-producing animals, wildlife and environment: a challenge for human health. Ital J Food Saf. 2019;8(2):7956. https://doi.org/10.4081/ijfs.2019.7956.

4. Dadgostar P. Antimicrobial resistance: implications and costs. Infect Drug Resist. 2019;12:3903-10. https://doi.org/10.2147/IDR.S234610.

5. Muhie OA. Antibiotic use and resistance pattern in Ethiopia: systematic review and meta-analysis. Int J Microbiol. 2019;2019:2489063.

6. Hughes JS, Hurford A, Finley RL, Patrick DM, Wu J, Morris AM. How to measure the impacts of antibiotic resistance and antibiotic development on empiric therapy: new composite indices. BMJ Open. 2016;6(12):e012040. https://doi.org/10.1136/bmjopen-2016-012040.

7. Breijyeh Z, Jubeh B, Karaman R. Resistance of gram-negative bacteria to current antibacterial agents and approaches to resolve it. Molecules. 2020; 25(6):1340. https://doi.org/10.3390/molecules25061340

8. Mirza S, Jadhav S, Misra RN, Das NK. Coexistence of $\beta$-lactamases in community-acquired infections in a tertiary care hospital in India. Int J Microbiol. 2019:2019:7019578.

9. Destoumieux-Garzón D, Mavingui P, Boetsch G, Boissier J, Darriet F, Duboz $P$, et al. The one health concept: 10 years old and a long road ahead. Front Vet Sci. 2018;5:14. https://doi.org/10.3389/fvets.2018.00014.

10. Tamma PD, Doi Y, Bonomo RA, Johnson JK, Simner PJ, Antibacterial Resistance Leadership Group, et al. A primer on AmpC $\beta$-lactamases: necessary knowledge for an increasingly multidrug-resistant world. Clin Infect Dis. 2019;69(8):1446-55. https://doi.org/10.1093/cid/ciz173.

11. Mohd Khari FI, Karunakaran R, Rosli R, Tee Tay S. Genotypic and phenotypic detection of AmpC $\beta$-lactamases in Enterobacter spp. isolated from a teaching hospital in Malaysia. PLoS One. 2016;11(3):e0150643.

12. Dandachi I, Chabou S, Daoud Z, Rolain JM. Prevalence and emergence of extended-spectrum cephalosporin-, carbapenem- and colistin-resistant gram negative bacteria of animal origin in the Mediterranean Basin. Front Microbiol. 2018;9:2299. https://doi.org/10.3389/fmicb.2018.02299.

13. Savin M, Bierbaum G, Hammerl JA, Heinemann C, Parcina M, Sib E, et al. ESKAPE bacteria and extended-spectrum- $\beta$-lactamase-producing Escherichia coli isolated from wastewater and process water from German poultry slaughterhouses. Appl Eenviron Microbiol. 2020;86(8):e02748-19.

14. Trongjit S, Angkittitrakul S, Chuanchuen R. Occurrence and molecular characteristics of antimicrobial resistance of Escherichia coli from broilers, pigs and meat products in Thailand and Cambodia provinces. Microbiol Immunol. 2016;60(9):575-85. https://doi.org/10.1111/1348-0421.12407.

15. Ejikeugwu C, Hasson SO, Al-Mosawi RM, Alkhudhairy MK, Saki M, Ezeador C, et al. Occurrence of FOX-1 AmpC gene among Pseudomonas aeruginosa isolates in abattoir samples from South-Eastern Nigeria. Rev Med Microbiol. 2020;31(2):99-103. https://doi.org/10.1097/MRM.0000000000000201.

16. Ejikeugwu C, Saki M, Nwakaeze E, Eze P, Orinya C, Duru C, et al. Characterization of bla $a_{\mathrm{MP}-1} \mathrm{MBL}$ genes among Klebsiella species from abattoir samples by multiplex PCR. Gene Rep. 2019;(16):100428. https://doi. org/10.1016/j.genrep.2019.100428.

17. McLellan JE, Pitcher Jl, Ballard SA, Grabsch EA, Bell JM, Barton M, et al. Superbugs in the supermarket? Assessing the rate of contamination with third-generation cephalosporin-resistant gram-negative bacteria in fresh 
Australian pork and chicken. Antimicrob Resist Infect Cont. 2018;7(1):30. https://doi.org/10.1186/s13756-018-0322-4.

18. Luo Q, Wang Y, Xiao Y. Prevalence and transmission of mobilized colistin resistance $(\mathrm{mcr})$ gene in bacteria common to animals and humans. Biosaf Health. 2020;2(2):71-8. https://doi.org/10.1016/j.bsheal.2020.05.001.

19. Nüesch-Inderbinen M, Treier A, Zurfluh K, Stephan R. Raw meat-based diets for companion animals: a potential source of transmission of pathogenic and antimicrobial-resistant Enterobacteriaceae. R Soc Open Sci. 2019;6(10): 191170. https://doi.org/10.1098/rsos.191170.

20. Founou LL, Founou RC, Essack SY. Antibiotic resistance in the food chain: a developing country-perspective. Front Microbiol. 2016;7:1881.

21. Otokunefor K, Agbude P, Otokunefor TV. Non-clinical isolates as potential reservoirs of antibiotic resistance in Port Harcourt, Nigeria. Pan Afr Med J. 2018;30:167.

22. Dan SD, Tabaran A, Mihaiu L, Mihaiu M. Antibiotic susceptibility and prevalence of foodborne pathogens in poultry meat in Romania. J Infect Dev Ctries. 2015;9(01):035-41. https://doi.org/10.3855/jidc.4958.

23. Talebiyan R, Kheradmand M, Khamesipour F, Rabiee-Faradonbeh M. Multiple antimicrobial resistance of Escherichia coli isolated from chickens in Iran. Vet Med Int. 2014;2014:491418.

24. Elhariri M, Hamza D, Elhelw R, Dorgham SM. Extended-spectrum betalactamase-producing Pseudomonas aeruginosa in camel in Egypt: potential human hazard. Ann Clin Microbiol Antimicrob. 2017;16(1):21. https://doi. org/10.1186/s12941-017-0197-x.

25. Dsani E, Afari EA, Danso-Appiah A, Kenu E, Kaburi BB, Egyir B. Antimicrobial resistance and molecular detection of extended spectrum $\beta$-lactamase producing Escherichia coli isolates from raw meat in Greater Accra region, Ghana. BMC Microbiol. 2020;20(1):1-8.

26. Elmanama AA, Al-Reefi MR, Shamali MA, Hemaid HI. Carbapenem-resistant gram-negative bacteria isolated from poultry samples: a cross-sectional study. Lancet. 2019;393:S21. https://doi.org/10.1016/S0140-6736(19)30607-5.

27. Falgenhauer L, Ghosh H, Guerra B, Yao Y, Fritzenwanker M, Fischer J, et al. Comparative genome analysis of InCHI2 VIM-1 carbapenemase-encoding plasmids of Escherichia coli and Salmonella enterica isolated from a livestock farm in Germany. Vet Microbiol. 2017;200:114-7. https://doi.org/10.1016/j. vetmic.2015.09.001.

28. Bajaj P, Singh NS, Virdi JS. Escherichia coli $\beta$-lactamases: what really matters. Front Microbiol. 2016;7:417.

29. Ibadin EE, Omoregie R, Anogie NA, Igbarumah IO, Ogefere HO. Prevalence of extended spectrum $\beta$-lactamase, AmpC $\beta$-lactamase and metallo- $\beta$ lactamase among gram negative bacilli recovered from clinical specimens in Benin city, Nigeria. Int J Enteric Pathog. 2017;5(3):85-91. https://doi.org/1 0.15171/ijep.2017.20

30. Iseppi R, de Niederhäusern S, Bondi M, Messi P, Sabia C. Extended-spectrum $\beta$-lactamase, AmpC, and MBL-producing gram-negative bacteria on fresh vegetables and ready-to-eat salads sold in local markets. Microb Drug Resist. 2018;24(8):1156-64. https://doi.org/10.1089/mdr.2017.0198.

31. Tewari R, Mitra S, Ganaie F, Das S, Chakraborty A, Venugopal N, et al. Dissemination and characterisation of Escherichia coli producing extendedspectrum $\beta$-lactamases, AmpC $\beta$-lactamases and metallo- $\beta$-lactamases from livestock and poultry in Northeast India: a molecular surveillance approach. J Glob Antimicrob Resist. 2019;17:209-15.

32. Hong JS, Song W, Park HM, Oh JY, Chae JC, Shin S, et al. Clonal spread of extended-spectrum cephalosporin-resistant Enterobacteriaceae between companion animals and humans in South Korea. Front Microbiol. 2019;10: 1371. https://doi.org/10.3389/fmicb.2019.01371.

33. Rensing KL, Abdallah HM, Koek A, Elmowalid GA, Vandenbroucke-Grauls CM, Al Naiemi N, et al. Prevalence of plasmid-mediated AmpC in Enterobacteriaceae isolated from humans and from retail meat in Zagazig, Egypt. Antimicrob Resist Infect Cont. 2019;8(1):1-8.

34. Saki M, Seyed-Mohammadi S, Montazeri EA, Siahpoosh A, Moosavian M, Latifi SM. In vitro antibacterial properties of Cinnamomum zeylanicum essential oil against clinical extensively drug-resistant bacteria. Eur J Integr Med. 2020;37:101146. https://doi.org/10.1016/j.eujim.2020.101146.

35. Clinical Laboratory Standard Institute. Performance standards for antimicrobial disk susceptibility test. CLSI supplement M100-S27. Wayne; 2017.

36. Ejikeugwu C, Iroha I, Amaechi CO, Ugwu M, Eze P, Iroha CS, et al. Multiple antibiotic resistance, antibiogram and phenotypic detection of metallobeta-lactamase (MBL) from Escherichia coli of poultry origin. J Appl Microbiol Biochem. 2017;1(4):1-6.
37. Sachdeva R, Sharma B, Sharma R. Evaluation of different phenotypic tests for detection of metallo- $\beta$-lactamases in imipenem-resistant Pseudomonas aeruginosa. J Lab Physicians. 2017;9(4):249-53. https://doi.org/10.4103/JLP. JLP_118_16.

38. Maraskolhe DL, Deotale VS, Mendiratta DK, Narang P. Comparision of three laboratory tests for detection of AmpC $\beta$ lactamases in Klebsiella species and E. Coli. J Clin Diagn Res. 2014;8(6):DC05-8. https://doi.org/10.7860/ JCDR/2014/8256.4432.

39. Mohamed MS, Hassan AT, Ahmed SM. Prevalence of carbapenemases among Klebsiella pneumoniae strains isolated from respiratory tract specimens. Egypt J Med Microbiol. 2016;38(105):1-8.

40. Schill F, Abdulmawjood A, Klein G, Reich F. Prevalence and characterization of extended-spectrum $\beta$-lactamase (ESBL) and AmpC $\beta$-lactamase producing Enterobacteriaceae in fresh pork meat at processing level in Germany. Int J Food Microbiol. 2017;257:58-66. https://doi.org/10.1016/j. ijfoodmicro.2017.06.010.

\section{Publisher's Note}

Springer Nature remains neutral with regard to jurisdictional claims in published maps and institutional affiliations.

\section{Ready to submit your research? Choose BMC and benefit from:}

- fast, convenient online submission

- thorough peer review by experienced researchers in your field

- rapid publication on acceptance

- support for research data, including large and complex data types

- gold Open Access which fosters wider collaboration and increased citations

- maximum visibility for your research: over $100 \mathrm{M}$ website views per year

At $\mathrm{BMC}$, research is always in progress.

Learn more biomedcentral.com/submissions 